\title{
Evaluasi Stabilitas Krim Ekstrak Nimba, Pegagan, dan Sirsak untuk Pengobatan Dermatitis pada Anjing
}

\author{
(STABILITY EVALUATION OF CREAM EXTRACT OF NEEM, GOTU KOLA AND \\ SOURSOP FOR DERMATITIS TREATMENT IN DOG)
}

\section{Nyoman Suartha ${ }^{1 *}$, Luh Made Sudimartini ${ }^{2}$, Ni Putu Ayu Dewi Wijayanti ${ }^{3}$,} ${ }^{1}$ Departemen Klinik Veteriner, Fakultas Kedokteran Hewan, Universitas Udayana, Jl. PB. Sudirman, Denpasar Bali; ${ }^{2}$ Departemen Fisiologi dan Farmakologi, Fakultas Kedokteran Hewan, Universitas Udayana, Jl. PB. Sudirman, Denpasar, Bali; ${ }^{3}$ Laboratorium Teknologi

Farmasi, Fakultas MIPA Universitas Udayana, Kampus Bukit Jimbaran.

*Email: nyoman_suartha@unud.ac.id

\begin{abstract}
Abstrak
Penelitian ini bertujuan untuk mengevaluasi stabilitas dari krim ekstrak herbal dengan komposisi kombinasi ekstrak daun nimba, pegagan, dan sirsak untuk membantu persembuhan penyakit radang kulit (Dermatitis) kompleks pada anjing. Secara in vitro ekstrak herbal di atas telah mampu menghambat pertumbuhan bakteri penyebab dermatitis. Penelitian ini dilakukan di Laboratorium Formulasi dan Teknologi Non Steril Jurusan Farmasi, Fakultas Matematika dan Ilmu Pengetahuan Alam Universitas Udayana.Sediaan krim dibuat dalam tiga formulasi, masing-masing formulasi dari sediaan tersebut di evaluasistabilitasnya pada suhu kamar. Evaluasi stabilitas sediaan krim meliputi uji organoleptik, uji homogenitas, uji $\mathrm{pH}$, uji daya lekat, uji daya sebar, dan uji viskositas. Hasil yang telah didapat sediaan krim stabil pada suhu ruang selama satu bulan dan formula yang stabil adalah formula 1. Disimpulkan krim ekstrak herbal formula 1 stabil pada suhu ruang selama satu bulan.

Kata kunci: Nimba; Azadiractha indika; Pegagan; Centella Asiatica; sirsak; Annona muricata; krim; stabilitas

Abstract

This study aims to evaluate the stability of herbal extract creams with a combination of neem leaves, gotu kola, and soursop extract to cure dermatitis complex in dogs., This herb extract has been able to inhibit in vitro the growth of bacteria that cause dermatitis. This research was conducted in the Laboratory of Non-Sterile Formulation and Technology at the Department of Pharmacy, Faculty of Mathematics and Natural Sciences, Udayana University. Cream preparations were made in three formulations; each formulation was evaluated for stability at room temperature. Evaluation of the stability of cream includes organoleptic test, homogeneity test, $\mathrm{pH}$ test, adhesion test, spreadability test, and viscosity test. The results showed the cream was stable at room temperature for one month and the stable formula was formula 1 . It can be concluded that the herb of formula 1 extract cream was stable at room temperature for one month.
\end{abstract}

Keywords: Neem, Azadiractha indika; gotu kola; Centella Asiatica; soursoup; Annona muricata; cream, stability

\section{PENDAHULUAN}

Keanekaragaman hayati tumbuhan Indonesia telah banyak digunakan sebagai obat tradisional untuk pemeliharaan kesehatan serta pengobatan (Mills, 1996). Penggunaan obat tradisional dipercaya memiliki khasiat empiris dan relatif lebih aman dibandingkan obat kimia (Deboer, 2005). Penggunaan obat herbal telah dilakukan sejak jaman dahulu, yang dibuktikan dengan telah tercantum pada kitab-kitab suci seperti kitab pengobatan Yayur Weda, Unani dan Homoeopathic (Kumar dan Navaratnam, 2013).

Pemanfaatan tumbuhan sebagai obat tradisional telah meningkat pesat baik di negara berkembang maupun negara maju (Kemenkes RI, 2007). Fenomena 
pemanfaatan obat tradisional yang semakin meningkat pada penggunaan untuk manusia juga sejalan dengan peningkatan penggunaan di hewan. Produk obat sebelum diedarkan ke penguna harus melalui tahapan-tahapan uji untuk mendapatkan produk yang aman, berkasiat, efektif dan mutu melalui pembuktian secara ilmiah.

Kasus dermatitis pada anjing dilaporkan sangat tinggi di berbagai daerah di Indonesia (Tjahajati, 2013; Widyastuti et al., 2012) Kejadian dermatitis kompleks tidak saja terjadi pada hewan kesayangan seperti anjing dan kucing, juga terjadi pada ternak produksi seperti babi, kambing, dan sapi (Suartha et al.,2014).

Penggunaan obat herbal untuk pengobatan dermatitis kompleks sangat menguntungkan karena negara Indonesia kaya bahan herbal itu dan tubuh dengan subur, disamping itu penggunaan obat herbal ini akan membantu masyarakat terutama pecinta hewan kesayangan, para petani dengan cara menanam tanaman herbal yang memiliki nilai ekonomis. Kegunaan yang lain yang dapat diperoleh adalah pelestarian lingkungan dan perlindungan tanaman langka. Penggunaan secara in vitro dilaboratorium kombinasi dari ekstrak tersebut telah mampu menghambat pertumbuhan dari bakteri penyebab dermatitis (Suartha et al., 2017). Pada penelitian ini di evaluasi stabilitas krim kombinasi ekstrak daun Nimba (Azadiractha indica), pegagan (Centella asiatica), dan daun sirsak (Annona muricata).

\section{METODE PENELITIAN}

\section{Rancangan Penelitian}

Penelitian ini menggunakan pendekatan eksperimental untuk mengevaluasi stabilitas sedia krim dengan bahan aktif ekstrak daun mimba, daun pegagan, dan daun sirsak. Evaluasi stabilitas sediaan krim dilakukan terhadap penyimpanan sediaan krim pada kisaran suhu ruang $27^{\circ} \mathrm{C}-28^{\circ} \mathrm{C}$ selama 28 hari. Variabel pengamatan yaitu organoleptis, $\mathrm{pH}$, daya sebar, viskositas dan daya lekat. Variabel organoleptis meliputi bau, warna, dan kkejernihan. Pengamatan dilakukan setiap 7 hari, kecuali variabel daya lekat diamati pada hari ke-0 dan hari ke-28. Penelitian ini dilakukan di Laboratorium Formulasi dan Teknologi Non Steril Jurusan Farmasi, Fakultas Matematika dan Ilmu Pengetahuan Alam Universitas Udayanapada bulan April-Juli 2018.

\section{Pembuatan Sediaan Krim}

Bahan baku yang digunakan dilakukan pengecekan secara meyeluruh sesuai dengan COA (Certificate of Analysis) dari masing-masing bahan dan dilakukan secara visual dengan melihat kondisi fisik bahan. Krim dibuat dalam tiga formulasi (Tabel 1).

Fase minyak (campuran 1) terdiri atas asam stearat, setil alkohol, cera alba, parafin cair, propil paraben dilebur dengan cawan porselen pada suhu $70^{\circ} \mathrm{C}$ di atas penangas air. Fase air (campuran 2) terdiri atas akuades, propilenglikol dan metil paraben dipanaskan di atas penangas air pada suhu $70^{\circ} \mathrm{C}$. Campuran 2 dimasukkan ke dalam Campuran 1 secara perlahan sambil diaduk dengan konstan dengan magnetic stirrer $500 \mathrm{rpm}$, pencampuran dilakukan diatas hotplate suhu $70^{\circ} \mathrm{C}$. Suhu diturunkan menjadi $45^{\circ} \mathrm{C}$, sambil tetap diaduk konstan sampai diperoleh massa krim yang homogen. Masing-masing ekstrak kental dari daun mimba, pegagan, sirsak digerus dalam mortar hingga homogen. Kemudian ditambahkan campuran krim sedikit demi sedikit kedalam mortar yang telah berisi ekstrak kental herbal sambil digerus sampai homogen. Krim dipindahkan kedalam pot krim dan diberi label.

\section{Uji Organoleptis}

Diamati ada tidaknya perubahan bau, perubahan warna dan pertumbuhan jamur pada sediaan. Pengamatan dilakukan setiap minggu selama 4 minggu (Rahmawati.et al., 2010). 


\section{Uji Homogenitas}

Uji homogenitas dilakukan dengan menimbang krim 1 gram dioleskan pada plat kaca, lalu digosok dan diraba. Bila homogen maka massa krim tidak tersisa bahan padatnyaatau tekstur nyata (Rahmawati et al., 2010).

Tabel 1. Komposisi formulasi sediaan krim

\begin{tabular}{llll}
\hline Bahan & Formula I & Formula 2 & Formula 3 \\
\hline Asam Stearat & $6,07 \mathrm{~g}$ & $7,02 \mathrm{~g}$ & $8,04 \mathrm{~g}$ \\
Setil alcohol & $2,03 \mathrm{~g}$ & $3,02 \mathrm{~g}$ & $4,01 \mathrm{~g}$ \\
Propilenglikol & $5 \mathrm{ml}$ & $5 \mathrm{ml}$ & $5 \mathrm{ml}$ \\
Parafin cair & $5 \mathrm{ml}$ & $5 \mathrm{ml}$ & $5 \mathrm{ml}$ \\
Cera alba & $6,506 \mathrm{~g}$ & $4,506 \mathrm{~g}$ & $2,501 \mathrm{~g}$ \\
Metil paraben & $0,181 \mathrm{~g}$ & $0,182 \mathrm{~g}$ & $0,181 \mathrm{~g}$ \\
Propil paraben & $0,02 \mathrm{~g}$ & $0,02 \mathrm{~g}$ & $0,02 \mathrm{~g}$ \\
Trietanolamin & $0,301 \mathrm{~g}$ & $0,302 \mathrm{~g}$ & $0,301 \mathrm{~g}$ \\
Ekstrak daun pegagan & $5,01 \mathrm{~g}$ & $5,05 \mathrm{~g}$ & $5,02 \mathrm{~g}$ \\
Ekstrak daun mimba & $5,02 \mathrm{~g}$ & $5,03 \mathrm{~g}$ & $5,01 \mathrm{~g}$ \\
Ekstrak daun sirsak & $5,04 \mathrm{~g}$ & $5,01 \mathrm{~g}$ & $5,01 \mathrm{~g}$ \\
Akuades & $60 \mathrm{ml}$ & $60 \mathrm{ml}$ & $60 \mathrm{ml}$ \\
\hline
\end{tabular}

\section{Uji Daya Lekat}

Uji daya lekat merupakan kemampuan dari sediaan untuk melekat pada kulit pada jangka waktu yang lama saat dipakai. Semakin lama daya lekat suatu sediaan, maka semakin lama waktu penetrasi obat akan maksimal

\section{Uji Daya Sebar}

Pemeriksaan daya sebar dilakukan dengan menggunakan 0,5 gram krim yang diletakkan ditengah kaca dan ditutup menggunakan plastik mika, selanjutnya ditindih dengan beban yang berbeda yaitu 50 gram, 100 gram, 150 gram dan 200 gram selama 1 menit, diukur daya sebar krim pada masing-masing beban.

\section{Uji Viskositas}

Uji viskositas dilakukan dengan menempatkan sediaan dalam beaker flask viscotester, viskositas sediaan diukur menggunakan viscometer Brooke field (DV-E) dengan spindle nomor 6 pada kecepatan 10-100 rpm. Pengujian dilakukan selama 4 minggu.

\section{Uji pH}

Pengukuran $\mathrm{pH}$ dilakukan dengan menggunakan $\mathrm{pH}$ meter. Sebelumnya $\mathrm{pH}$ meter dikalibrasi dengan larutan standar buffer dengan $\mathrm{pH}$ 4,7 dan 10 (Elya et al., 2013).

\section{HASIL DAN PEMBAHASAN}

\section{Stabilitas Krim Herbal}

Penelitian ini dilakukan untuk mengetahui dan membandingkan stabilitas sediaan krim 3 ekstrak yaitu ekstrak mimba, pegagan dan sirsak secara fisik dengan konsentrasi asam stearate, setil alkohol dan cera alba yang berbeda-beda. Perbedaan asam stearate, setil alkohol, dan cera alba dimaksudkan untuk melihat formulasi krim dengan daya lekat yang tinggi yang akan diaplikasikan pada kulit hewan yang berbulu. Selain itu untuk membandingkan perbedaan stabilitas fisik 3 formulasi sediaan krim, sehingga didapatkan formula yang memiliki sifat fisik yang memiliki stabilitas fisik yang paling baik. Kestabilan emulsi farmasi bercirikan tidak adanya penggabungan fase dalam, tidak ada creaming dan memberikan penampilan bau, warna, serta sifat-sifat fisik yang baik dan tidak berubah dari keadaan awal. Uji stabilitas sediaan krim dilakukan setiap seminggu selama 1 bulan dalam temperatur ruang $\pm 25^{\circ} \mathrm{C}$ meliputi organoleptis, homogenitas, daya lekat, daya sebar, $\mathrm{pH}$ dan viskositas. Masing-masing 
formulasi diberikan perlakuan yang sama.

\section{Organoleptis}

Telah dilakukan pengamatan organoleptis pada penyimpanan suhu ruang $\pm 25^{\circ} \mathrm{C}$. Parameter uji organoleptis meliputi perubahan bau, perubahan warna dan pertumbuhan jamur. Pengamatan dilakukan setiap minggu selama 4 minggu penyimpanan. Hasil Pengamatan organoleptis dapat dilihat pada Table 2 .
Selama perlakuan tidak terjadi perubahan bau, perubahan warna, dan pertumbuhan jamur selama 4 minggu penyimpanan baik pada F1, F2, dan F3 (Tabel 2). Sediaan krim memiliki bentuk yang semisolid dan tekstur yang lembut serta memiliki bau khas dedaunan. Masingmasing sediaan krim memiliki warna hijau tua diakibatkan karena tingginya konsentrasi ekstrak yang digunakan yaitu sebesar $15 \%$.

Tabel 2. Hasil pengamatan organoleptis sediaan

\begin{tabular}{llllllllll}
\hline \multirow{2}{*}{ Minggu ke- } & \multicolumn{3}{c}{ Formula 1 } & \multicolumn{3}{c}{ Formula 2 } & \multicolumn{3}{c}{ Formula 3 } \\
\cline { 2 - 9 } & PB & PW & PJ & PB & PW & PJ & PB & PW & PJ \\
\hline $\mathbf{1}$ & - & - & - & - & - & - & - & - & - \\
$\mathbf{2}$ & - & - & - & - & - & - & - & - & - \\
$\mathbf{3}$ & - & - & - & - & - & - & - & - & - \\
$\mathbf{4}$ & - & - & - & - & - & - & - & - & - \\
\hline
\end{tabular}

Keterangan: $\mathrm{PB}=$ Perubahan Bau; $\mathrm{PW}=$ Perubahan Warna; PJ $=$ Perubahan Jamur; $(-)=$ Tidak Terjadi; $(+)=$ Terjadi

Pemeriksaan krim secara organoleptis tidak menunjukkan adanya perbedaan warna pada sediaan krim F1, F2, dan F3. Ketiganya memiliki warna yang sama dari awal pemeriksaan sampai akhir pemeriksaan secara organoleptis selama 28 hari. Sediaan krim yang dihasilkan memiliki kriteria krim yang baik yaitu tidak menimbulkan bau atau ketengikan, tidak adanya perubahan warna dan jamur (Gambar 1).

\section{Uji Homogenitas}

Sediaan krim kombinasi ekstrak mimba, pegagan dan sirsak diambil secukupnya kemudian dioleskan pada gelas objek atau kepingan kaca untuk pengujian homogenitas. Kriteria krim yang baik harus homogen dan bebas dari partikel-partikel yang masih menggumpal. Sediaan krim yang homogen adalah sediaan krim dimana dasar krim, bahan aktif, dan bahan tambahan lainnya tercampur merata dengan baik. Sediaan krim yang tidak homogen akan diketahui dengan melihat terbentuknya gumpalan pada sediaan. Berikut hasil pengamatan uji homogenitas dari ketiga formulasi (Gambar 2).

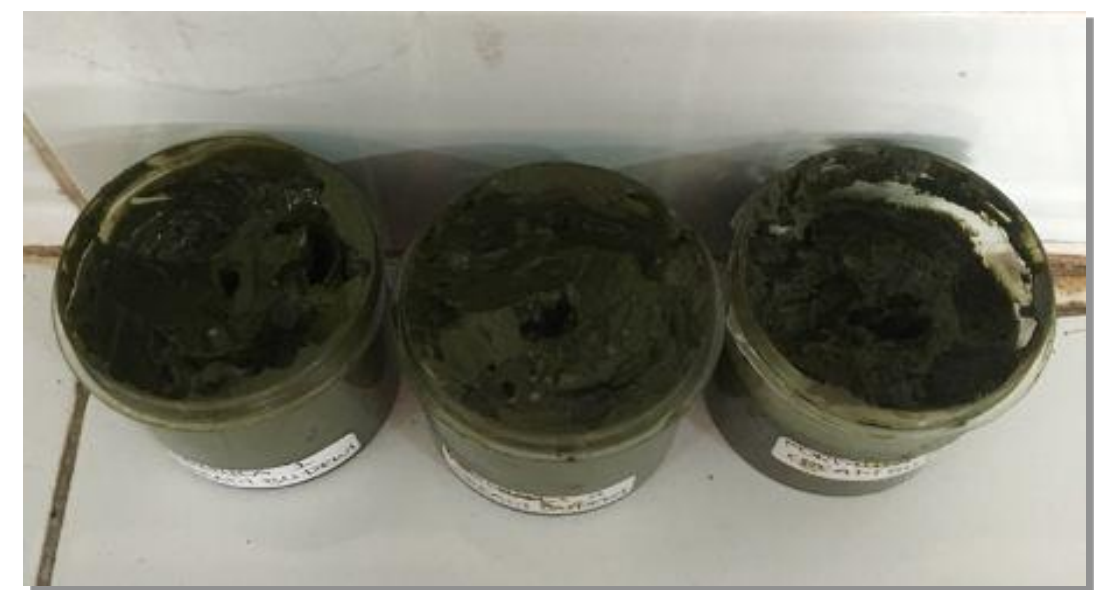

Gambar 1. Pengamatan Organoleptis Krim Kombinasi 3 Ekstrak 

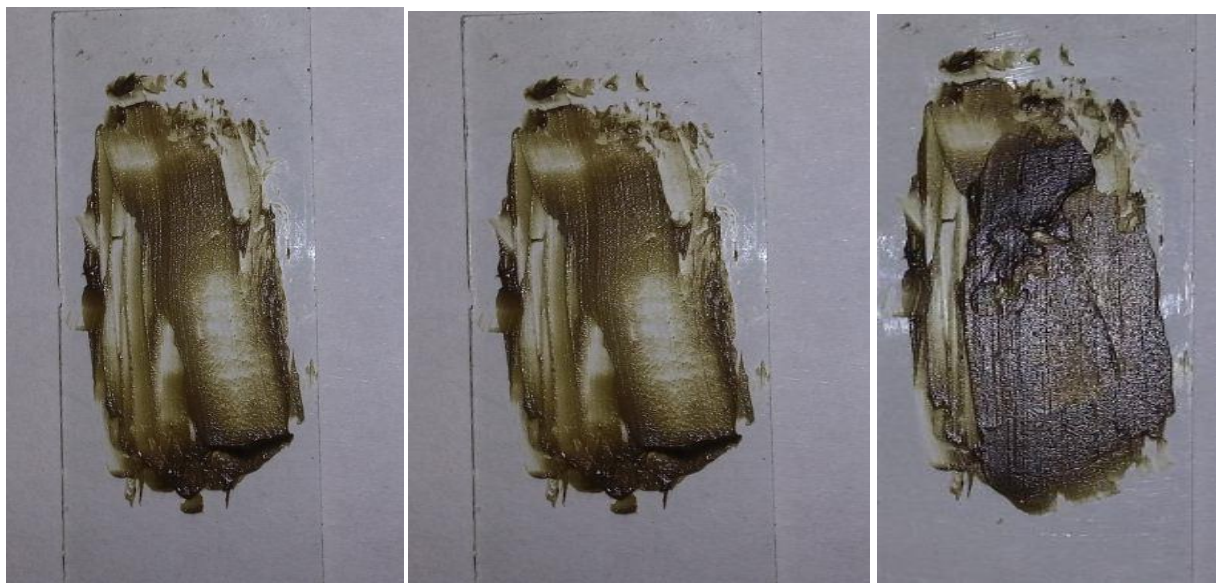

Gambar 2. Hasil Pengamatan Uji Homogenitas 3 Formulasi dari F1, F2 dan F3

Hasil uji homogenitas yang dilakukan didapatkan bahan-bahan dari sediaan krim tercampur dan tersebar menjadi homogen. Dari ketiga formulasi dilakukan pengamatan visual tidak menunjukan terbentuknya butiran kasar atau gumpalan. Pada bagian sediaan krim yang dioleskan pada kaca memiliki sifat fisik dan tekstur Tabel 3. Hasil uji pH sediaan krim yang sama. Hasil uji homogenitas yang dilakukan pada setiap sediaan krim terbukti homogeny apabila tidak terdapat partikelpartikel yang menggumpal.

\section{Pengukuran pH}

Data $\mathrm{pH}$ sediaan krim untuk tiap formula dapat dilihat pada Tabel 3 .

\begin{tabular}{llll}
\hline \multirow{2}{*}{ Minggu ke- } & \multicolumn{2}{c}{ pH } \\
\cline { 2 - 4 } & Formula I & Formula II & Formula III \\
\hline $\mathbf{0}$ & 5,68 & 5,42 & 5,05 \\
$\mathbf{1}$ & 5,89 & 5,62 & 5,10 \\
$\mathbf{2}$ & 5,62 & 5,8 & 5,16 \\
$\mathbf{3}$ & 5,71 & 5,33 & 5,32 \\
$\mathbf{4}$ & 6,02 & 5,3 & 5,28 \\
\hline
\end{tabular}

Data $\mathrm{pH}$ pada Tabel 3 menunjukkan bahwa tiap formula menghasilkan nilai $\mathrm{pH}$ yang berbeda. Rentang nilai $\mathrm{pH}$ kulit anjing adalah 5,5-7,2 (Matuosek, et al., 2003) hanya formula satu yang memenuhi persyaratan $\mathrm{pH}$ dari kulit anjing dari awal pembuatan hingga akhir pengamatan yaitu setelah disimpan selama empat minggu. Pemeriksaan $\mathrm{pH}$ sediaan merupakan parameter fisikokimia yang harus dilakukan untuk sediaan topikal karena $\mathrm{pH}$ mempunyai kaitan dengan stabilitas sediaan, kenyamanan dikulit sewaktu digunakan, dan penetrasi zat aktif (Melani, 2005). Sehingga dapat dikatakan formula satu tidak akan mengiritasi kulit anjing dan penetrasi zat aktif akan lebih maksimal dibanding formula lainnya karena formula satu memiliki nilai $\mathrm{pH}$ yang paling mendekati $\mathrm{pH}$ fisiologis kulit anjing.

\section{Daya Sebar}

Pengukuran daya sebar dilakukan terhadap 3 sediaan krim. Data daya sebar sediaan krim untuk tiap formula dari minggu ke-0 sampai minggu ke-4 dapat dilihat pada Tabel 4.

Berdasarkan dari data yang diperoleh formula 1 memiliki nilai daya sebar yang paling besar dibandingkan formula lainnya. Daya sebar masing-masing formula dipengaruhi oleh komposisi asam sterarat, cera alba dan setil alkohol yang digunakan. Semakin rendah komponen padat yang terdapat dalam sediaan krim maka semakin besar daya sediaan untuk menyebar, begitu pula sebaliknya. 
Tabel 4 Tabel daya sebar sediaan krim

\begin{tabular}{llllll}
\hline \multirow{2}{*}{ Formula } & \multicolumn{5}{c}{ Beban } \\
\cline { 2 - 6 } Minggu ke-0 & Awal & $\mathbf{5 0} \mathbf{~ g r}$ & $\mathbf{1 0 0} \mathbf{~ g r}$ & $\mathbf{1 5 0} \mathbf{~ g r}$ & $\mathbf{2 0 0} \mathbf{~ g r}$ \\
I & & & & & \\
II & $2 \times 2 \mathrm{~cm}$ & $3,1 \times 3 \mathrm{~cm}$ & $4,0 \times 3,8 \mathrm{~cm}$ & $4,4 \times 4,0 \mathrm{~cm}$ & $5,2 \times 5,0 \mathrm{~cm}$ \\
III & $2,3 \times 3 \mathrm{~cm}$ & $3,3 \times 3 \mathrm{~cm}$ & $3,9 \times 3,7 \mathrm{~cm}$ & $4,6 \times 4,5 \mathrm{~cm}$ & $5,5 \times 5,4 \mathrm{~cm}$ \\
Minggu ke-1 & $2,1 \times 2 \mathrm{~cm}$ & $3,3 \times 2,8 \mathrm{~cm}$ & $4,0 \times 3,5 \mathrm{~cm}$ & $4,4 \times 4,1 \mathrm{~cm}$ & $5,3 \times 5 \mathrm{~cm}$ \\
I & $1,8 \times 1,7 \mathrm{~cm}$ & $2 \times 1,8 \mathrm{~cm}$ & $2,4 \times 2,4 \mathrm{~cm}$ & $2,7 \times 2,5 \mathrm{~cm}$ & $3 \times 2,7 \mathrm{~cm}$ \\
II & $2 \times 1,2 \mathrm{~cm}$ & $2,1 \times 1,8 \mathrm{~cm}$ & $2,8 \times 2,4 \mathrm{~cm}$ & $3,1 \times 3 \mathrm{~cm}$ & $3,8 \times 3,2 \mathrm{~cm}$ \\
III & $2 \times 1,8 \mathrm{~cm}$ & $3 \times 2,6 \mathrm{~cm}$ & $3,4 \times 2,8 \mathrm{~cm}$ & $3,5 \times 2,9 \mathrm{~cm}$ & $3,7 \times 3,4 \mathrm{~cm}$ \\
Minggu ke-2 & & & & & \\
I & $2 \times 2 \mathrm{~cm}$ & $2,3 \times 2,3 \mathrm{~cm}$ & $2,9 \times 2,7 \mathrm{~cm}$ & $3,1 \times 2,8 \mathrm{~cm}$ & $3,4 \times 3,1 \mathrm{~cm}$ \\
II & $2 \times 2 \mathrm{~cm}$ & $2,3 \times 2 \mathrm{~cm}$ & $2,5 \times 2,5 \mathrm{~cm}$ & $3 \times 2,8 \mathrm{~cm}$ & $3,2 \times 3 \mathrm{~cm}$ \\
III & $2 \times 2 \mathrm{~cm}$ & $2,2 \times 2,1 \mathrm{~cm}$ & $2,5 \times 2,4 \mathrm{~cm}$ & $3 \times 2,7 \mathrm{~cm}$ & $3,3 \times 3 \mathrm{~cm}$ \\
Minggu ke-3 & & & & & \\
I & $2 \times 2 \mathrm{~cm}$ & $2,3 \times 2,3 \mathrm{~cm}$ & $2,9 \times 2,7 \mathrm{~cm}$ & $3,1 \times 2,8 \mathrm{~cm}$ & $3,4 \times 3,1 \mathrm{~cm}$ \\
II & $2 \times 2 \mathrm{~cm}$ & $2,2 \times 2,5 \mathrm{~cm}$ & $2,5 \times 2,5 \mathrm{~cm}$ & $3 \times 2,8 \mathrm{~cm}$ & $3,2 \times 3 \mathrm{~cm}$ \\
III & $2 \times 2 \mathrm{~cm}$ & $2,2 \times 2,1 \mathrm{~cm}$ & $2,5 \times 2,4 \mathrm{~cm}$ & $3 \times 2,7 \mathrm{~cm}$ & $3,3 \times 3 \mathrm{~cm}$ \\
Minggu ke-4 & & & & & \\
I & $2 \times 2 \mathrm{~cm}$ & $2,3 \times 2,3 \mathrm{~cm}$ & $2,9 \times 2,7 \mathrm{~cm}$ & $3,1 \times 2,8 \mathrm{~cm}$ & $3,4 \times 3,1 \mathrm{~cm}$ \\
II & $2 \times 2 \mathrm{~cm}$ & $2,5 \times 2,2 \mathrm{~cm}$ & $2,5 \times 2,5 \mathrm{~cm}$ & $3 \times 2,8 \mathrm{~cm}$ & $3,2 \times 3 \mathrm{~cm}$ \\
III & $2 \times 2 \mathrm{~cm}$ & $2,2 \times 2,1 \mathrm{~cm}$ & $2,5 \times 2,4 \mathrm{~cm}$ & $3 \times 2,7 \mathrm{~cm}$ & $3,3 \times 3 \mathrm{~cm}$ \\
\hline
\end{tabular}

\section{Daya Lekat}

Pengukuran daya lekat dilakukan terhadap 3 sediaan krim. Data daya lekat sediaan krim untuk tiap formula dapat dilihat pada Tabel 5. Pengujian daya lekat bertujuan untuk mengetahui kemampuan krim melekat pada kulit anjing. Berdasarkan data yang diperoleh, pada minggu ke-0 menuju minggu ke-4 terjadi peningkatan daya lekat terhadap krim yang dibuat. Formula dua memiliki daya lekat yang lebih tinggi dibandingkan dengan formula satu dan tiga. Krim yang baik memiliki daya lekat yang tinggi. Kemampuan daya lekat krim akan mempengaruhi penetrasi zat aktif ke kulit. Semakin lama kemampuan krim melekat pada kulit, maka krim dapat memberikan efek terapi yang lebih lama (Ansel, 2008).

Tabel. 5 Data daya lekat sdiaan krim

\begin{tabular}{clll}
\hline \multirow{2}{*}{ Minggu ke-- } & \multicolumn{3}{c}{ Daya Lekat } \\
\cline { 2 - 4 } & Formula I & Formula II & Formula III \\
\hline $\mathbf{0}$ & 0,60 detik & 0,42 detik & 0,41 detik \\
$\mathbf{1}$ & 1,02 detik & 1,97 detik & 1,80 detik \\
$\mathbf{2}$ & 1,03 detik & 1,24 detik & 1,03 detik \\
$\mathbf{3}$ & 2,47 detik & 2,64 detik & 2,37 detik \\
$\mathbf{4}$ & 2,37 detik & 2,49 detik & 2,27 detik \\
\hline
\end{tabular}

\section{Viskositas}

Pengukuran viskositas dilakukan terhadap 3 sediaan krim menggunakan alat viscometer Brookfield. Data viskositas sediaan krim untuk tiap formula dapat dilihat pada Tabel 6 dan Gambar 3. Tabel 6 menunjukkan bahwa viskositas awal dari yang tertinggi hingga terendah berturutturut diperoleh pada Formula $1(5430 \mathrm{cps})$, Formula 2 (5210 cps), formula 3 (2810 
cps), hal ini menunjukkan bahwa nilai viskositas bergantung pada perbandingan konsentrasi asam stearat, setil alkohol dan cera alba yang digunakan, penggunaan cera alba pada formula satu paling besar dibandingkan dengan formua 2 dan 3 . Berdasarkan Gambar 1 terlihat bahwa nilai viskositas formula 1 dan 2 meningkat pada minggu pertama kemudian menurun tajam pada minggu kedua dan cenderung stabil sampai minggu keempat. Berbeda dengan formula 3 yang memiliki nilai viskositas awal yang paling rendah sehinggapada minggu kedua tidak terjadi penurunan viskositas yang tajam. Rendahnya nilai viskositas pada formula 3 pada minggu awal pengukuran menunjukkan sediaan krim yang lebih encer dibandingkan dengan formula satu dan dua. Meningkatnya viskositas pada minggu pertama disebabkan karena proporsi fase terdispersi meningkat sehingga ukuran diameter partikel semakin kecil danluas permukaannya besar akibatnya dibutuhkan gaya geser yag lebih tinggi. Penurunan viskositas pada minggu kedua disebabkan karena kenaikan ukuran diameter partikel yang menyebabkan luas permukaannya semakin kecil sehingga mengakibatkan viskositas menurun (Dewi et al., 2016).

Tabel 6. Data viskositas pada penyimpanan suhu ruang

\begin{tabular}{clllll}
\hline \multirow{2}{*}{ Formula } & \multicolumn{5}{c}{ Viskositas } \\
\cline { 2 - 6 } & Minggu ke-0 & Minggu ke-1 & Minggu ke-2 & Minggu ke-3 & Minggu ke-4 \\
\hline 1 & 4040 & 5430 & 660 & 640 & 500 \\
2 & 3800 & 5210 & 420 & 290 & 200 \\
3 & 2050 & 2810 & 310 & 210 & 130 \\
\hline
\end{tabular}

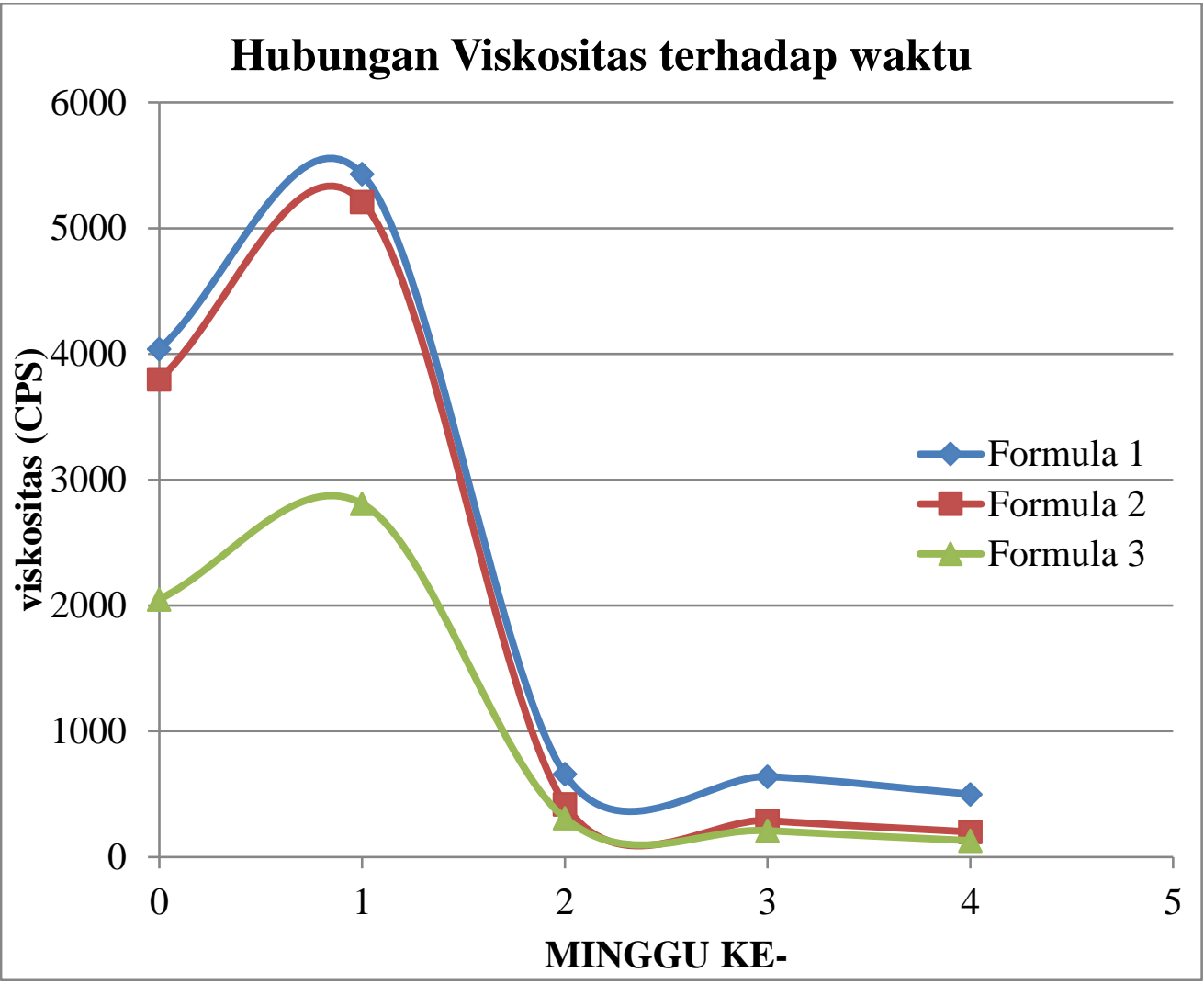

Gambar 1. Profil kestabilan viskositas 


\section{SIMPULAN DAN SARAN}

\section{Simpulan}

Disimpulkan krim ekstrak herbal formula 1 stabil pada suhu ruang selama satu bulan.

\section{Saran}

Disarankan sedia formula 1 dari krim dapat digunakan untuk pengobatan dermatitis pada anjing.

\section{UCAPAN TERIMAKASIH}

Penulis mengucapkan terima kasih kepada Kemenristekdikti melalui Rektor Unud atas bantun dana penelitian, dari dana DIPA PNBP FKH Universitas Udayana TA-2018, melalui hibah Penellitian Unggulan Universitas, Sesuai dengan Surat Perjanjian Penugasan Pelaksanaan Penelitian Nomor: 0800/UN.14.2.9/LT/ 2018, tanggal 5 April 2018.

\section{DAFTAR PUSTAKA}

Ansel HC. 2008. Pengantar bentuk sediaan farmasi. Jakarta: UI Press.

DeBoer DJ. 2005. Cutaneous adverse drug reactions. Proc. of the NAVC North American Veterinary Conference, Orlando, Florida. 8-12, Jan 2005.

Dewi R, Anwar E, Yunita KS. 2016. Uji stabilitas fisik formula krim yang mengandung ekstrak kacang kedelai (Glycine max). Pharm. Sci. Res. 1(3): 194-208.

Elya B, Dewi R, Haqqi, Budiman M. 2013. Antioxidant cream of Salanum lycopersium L. Int. J. Pharm. Tech. Res. 5(1): 233-238.

Ita H, Amaliah, Danial M. 2015. Efektivitas salep ekstrak daun sirsak (Annona muricata L.) pada mencit yang terinfeksi bakteri Staphylococcus aureus. Proc. Seminar Nasonal Mikrobiologi Kesehatan Lingkungan. Jurusan Biologi. FMIPA. UIN Allaudin Makasar.

Keputusan Menteri Kesehatan Republik Indonesia. 2007. Kebijakan obat tradisional nasional tahun 2007.
Jakarta: Departemen Kesehatan Republik Indonesia.

Kumar VS, Navaratnam V. 2013. Nimba (Azadirachta indica): Prehistory to contemporary medicinal uses to human kind. Asian Pac. J. Trop. Biomed. 3(7): 505-514.

Matousek JL, Campbell KL, Kakoma I, Solter PF, Schaeffer DJ. 2003 Evaluation of the effect of $\mathrm{pH}$ on in vitro growth of malassezia pachydermatis. Canadian J. Vet. Res. 67(1): 56-59.

Melani D, Purwati T, Soeratri W. 2005. Koerelasi kadar propilenglikol dalam basis dan pelepasan dietilammonium diklofenak dari basis carbopol ETD 2020. Majalah Farmasi Airlangga. 5(1): 1-6.

Mills S. 1996. Pengobatan alternative. Terjemahan: P. Boentaran, Dian Rakyat, Jakarta.

Rahmawati D, Sukmawati A, Indrayudha P. 2010 Formulasi krim minyak atsiri rimpang temu giring (Curcuma heyneanar Val \& Zijp): uji sifat fisik dan daya antijamur terhadap Candida albicans ecara in vitro. Maj. Obat Trad. 15: 56-63.

Suartha IN, Septyawati R, Gunata IK. 2014. Bentuk dan sebaran lesi demodekosis pada sapi bali. J. Vet. 15(3): 395-400.

Suartha IN, Suarjana IGK, Sudimartini LM, Swantara IMD. 2017. In vitro study of antimicrobial activity of combined extracts of Azadiractha indica, Centella Asiatica and Annona muricata leaves against a panel of bacteria isolated from dog dermatitis cases. Lembaga Penelitian dan Pengabdian Masyarakat, Unud, Bali.

Tjahajati I. 2013. Update common parasitic disease in dog. Seminar Ilmiah Dokter Hewan. 14 Nopember 2013. Pulmann Hotel Bali.

Widyastuti SK, Sutaridewi NM, Utama IH. 2012. Kelainan kulit anjing jalanan pada beberapa lokasi di Bali. Buletin Vet. Udayana. 4(2): 81-86. 
